\title{
Absence of geographical structure of chloroplast DNA variation in sallow, Salix caprea L.
}

\author{
AE Palmé, V Semerikov and M Lascoux \\ Department of Conservation Biology and Genetics, Evolutionary Biology Centre, Uppsala University, Norbyvägen 18 D, 75236 \\ Uppsala, Sweden
}

\begin{abstract}
In the present study, we have used PCR-RFLP markers to investigate the chloroplast DNA variation in 24 European populations of Salix caprea L. A subset of these populations has also been analysed with chloroplast microsatellites. The main feature of both markers is the absence of a clear geographic structure $\left(G_{\mathrm{ST} \text { (PCR-RFLP })}=0.090\right.$, $G_{S T \text { (microsatellites) }}=-0.017$ ) and high levels of variation within populations. This lack of phylogeographic structure in $S$. caprea is suggested to be the consequence of the joint action of several factors: (i) presence of intermediate latitude refugia with large population sizes during the last glacial maximum, (ii) a high speed of recolonisation and dispersal
\end{abstract}

ability, (iii) a high mutation rate and (iv) extensive hybridisation with other willow species. In addition to the $S$. caprea samples, a limited number of individuals from several other Salix species were also analysed with PCR-RFLP: $S$. cinerea, S. aurita, S. purpurea, S. atrocinerea, S. appendiculata, $S$. elaeagnos, $S$. fragilis and $S$. alba. Many of the haplotypes found in Salix caprea were also detected in $S$. cinerea, S. aurita, S. purpurea, $S$. atrocinerea and/ or $S$. appendiculata but not in $S$. alba, $S$. elaeagnos or $S$. fragilis. Our data suggest that hybridisation and gene flow have occurred within these two groups but not between them. Heredity (2003) 91, 465-474. doi:10.1038/sj.hdy.6800307

Keywords: Salix caprea; chloroplast DNA; phylogeography; hybridisation; postglacial recolonisation

\section{Introduction}

Cytoplasmic markers have undoubtedly been useful in recovering post-glacial migration routes for a range of organisms (Taberlet et al, 1998; Hewitt, 2000). In trees, recolonisation patterns have been unravelled in, among others, Quercus (Petit et al, 2002), Fagus (Demesure et al, 1996) and Picea (Vendramin et al, 2000) by combining information from chloroplast DNA and fossil pollen maps. In most cases, the fixation index, a classical measure of the genetic differentiation among populations, had a very high value. A recent review (RJ Petit, unpublished) shows that the average fixation index for chloroplast DNA in the angiosperm species that have been studied so far is about $76 \%$, the lowest value being $25 \%$. These values are fairly high, although not completely unexpected. Chloroplast DNA is generally maternally inherited in angiosperms (Rajora and Dancik, 1992; Dumolin et al, 1995) and has therefore a smaller effective population size than nuclear DNA $(1 / 4$ in dioecious species and $1 / 2$ in monoecious ones). Maternal inheritance also means that chloroplast DNA is only dispersed through seeds. Smaller effective population sizes and restricted dispersal thus imply that genetic differentiation among populations is generally more pronounced for chloroplast DNA than nuclear DNA.

There are however reasons to believe that the clear geographic structure obtained, for example, in oaks or

Correspondence: A Palmé, Department of Conservation Biology and Genetics, Evolutionary Biology Centre, Norbyvägen 18 D, Uppsala University, 75236 Uppsala, Sweden. E-mail: anna.palme@ebc.uu.se Received 15 February 2002; accepted 3 March 2003 beech, may not be found in other species, making it difficult to decipher their evolutionary history in relation to climatic changes affecting their distribution. First, oaks and beech are not cold tolerant and were therefore confined to refugia in Southern Europe during the last glacial maximum (LGM). These refugia were probably of limited size and isolated from each other, allowing for population differentiation to develop among refugia. Other species, such as birches, pines, spruces or larches, are cold tolerant and were apparently able to survive the LGM at higher latitudes (Willis et al, 2000). Macroscopic charcoal remains of Salix dated to about $23000{ }^{14} \mathrm{C}$ years $\mathrm{BP}$ have been found in Hungary, indicating survival at these latitudes, but it has not been possible to determine the exact Salix species (Willis et al, 2000). Second, the recolonisation process for the species studied so far, especially beech, was relatively slow when compared to the rate at which species such as birch (Betula) or hazel (Corylus) may have colonised northern Europe as the ice retreated (Huntley and Birks, 1983; Bennett, 1997). Third, the mutation rate must be sufficiently low so as not to erase the phylogeographic information. Chloroplast mutation rates are poorly known, but may vary among species (Bousquet et al, 1992). Fourth, while hybridisation in oaks apparently occurred during the recolonisation process of northern Europe, it remained confined to a few species. A more extensive hybridisation pattern could potentially weaken the phylogeographic signal carried by a given species.

Sallow is a cold-tolerant pioneer species which occurs in a large range of habitats and is one of the few willow species able to grow in forest understories (Rameau et al, 1989). Its natural range covers much of Europe except the 
most northern and southern parts (Tutin et al, 1964) and it also extends into Asia. Many members of the Salix genus are known to hybridise with each other, and Salix caprea in particular hybridises with a number of other Salix species (Tutin et al, 1964; Meikle, 1984). The extent of gene flow among natural populations remains, however, unknown. The fossil pollen record is difficult to interpret since the pollen of different Salix species cannot be distinguished (Huntley and Birks, 1983). Sallow is certainly cold resistant enough to be able to survive at high latitudes during the LGM. Finally, sallow is dioecious increasing the likelihood of detecting high levels of differentiation for chloroplast DNA markers.

The main objective of this study is to investigate the phylogeographic structure of genetic variation in S. caprea L. across Europe. To do so, chloroplast DNA variation was studied in 24 S. caprea populations distributed across a large part of the species' natural range. In addition, other willow species that could potentially hybridise with $S$. caprea were included since hybridisation was suspected to be important in S. caprea.

\section{Material and methods}

\section{Sampling}

S. caprea was sampled in 24 locations across Europe (Table 1 and Figure 1). Most samples consisted of leaves, although buds were collected from populations in Croatia, Romania, Slovakia and Greece. In each location samples from about 10 individuals were gathered, making a total sample of 240 S. caprea individuals. A more limited number of samples were also collected in populations of $S$. cinerea, S. aurita, S. purpurea, S. atrocinerea, S. appendiculata, S. elaeagnos, S. fragilis and S. alba $(31,7,5,11,5,2,1$ and 21 individuals, respectively; Table 1). According to Skvortsov (1968) S. caprea, S. cinerea, S. aurita, S. purpurea, S. atrocinerea and $S$. appendiculata all belong to the subgenus Vetrix, subsection Vetrix, while S. fragilis and S. alba belong to subgenus Salix, subsection Salix (S. elaeagnos was not included in this study). Most of these species have a wide distribution across Europe but $S$. atrocinerea is restricted to western Europe, S. appendiculata to the Alpine region, Italy and the Balkans, and S. elaeagnos is only found in the southern half of Europe (Jalas et al, 1996). To avoid sampling clones or close relatives, sampled individuals of the same species were separated by at least $200 \mathrm{~m}$.

The leaf samples were frozen in liquid nitrogen in the field or kept fresh until they could be frozen in a $-80^{\circ} \mathrm{C}$ freezer. These samples, if we did not collect them ourselves, were sent to us by express mail frozen in dry ice. The buds were collected as whole branches, stored at about $4^{\circ} \mathrm{C}$ and then sent by express mail to our lab. They were then separated from the branches, frozen and subsequently stored at $-80^{\circ} \mathrm{C}$.

\section{DNA extraction}

DNA was extracted with a protocol adapted from Doyle and Doyle (1990). Leaf or bud tissue was ground in liquid nitrogen and about $10 \mathrm{mg}$ of this powder was added to $800 \mathrm{ml}$ of extraction buffer. The extraction buffer used consists of alkyltrimethammonium bromide $(20 \mathrm{~g} / \mathrm{l})$, EDTA $(0.02 \mathrm{M})$, Tris $\mathrm{HCl}(0.1 \mathrm{M}), \mathrm{NaCl}(1.4 \mathrm{M})$

Table 1 Sampling locations where Salix caprea and in some cases also other Salix species have been collected

\begin{tabular}{|c|c|c|c|c|c|c|c|c|c|c|c|c|c|}
\hline Population & Country & Code & Longitude & Latitude & $\begin{array}{c}\text { Salix } \\
\text { caprea }\end{array}$ & $S C I$ & $S A U$ & SPU & SAT & $S A P$ & SEL & SFR & $S A L$ \\
\hline Glen Affric & Great Britain & 1 & -4.83 & 57.32 & 8 & - & - & - & - & - & - & - & - \\
\hline Lake District & Great Britain & 2 & -3.00 & 54.27 & 10 & - & - & - & - & - & - & - & - \\
\hline Dean & Great Britain & 3 & -2.65 & 51.83 & 10 & - & - & - & - & - & - & - & - \\
\hline Tofta & Sweden & 4 & 11.7 & 57.87 & 11 & 3 & - & - & - & - & - & - & - \\
\hline Stenshuvud & Sweden & 5 & 14.25 & 55.65 & 11 & - & - & - & - & - & - & - & - \\
\hline Halltorps Hage & Sweden & 6 & 16.53 & 56.75 & 9 & 3 & 3 & - & - & - & - & - & - \\
\hline Seebachtal & Germany & 7 & 8.12 & 47.88 & 11 & - & - & - & - & 5 & - & - & - \\
\hline Bovenden & Germany & 8 & 10.05 & 51.57 & 10 & - & - & - & - & - & - & - & - \\
\hline Kelheim & Germany & 9 & 11.83 & 48.93 & 9 & - & - & - & - & - & - & - & - \\
\hline Fontainebleau & France & 10 & 2.67 & 48.42 & 8 & 6 & 1 & - & - & - & - & - & 1 \\
\hline Chizé & France & 11 & -0.40 & 46.14 & 9 & - & - & - & - & - & - & 1 & - \\
\hline Seillon & France & 12 & 5.00 & 46.00 & 10 & 3 & 3 & - & - & - & - & - & 3 \\
\hline Valbonne & France & 13 & 4.55 & 44.24 & 10 & - & - & 1 & - & - & 1 & - & 5 \\
\hline Valdu Niellu, Aitone & Corsica, France & 14 & 8.88 & 42.28 & 13 & 6 & - & 4 & 1 & - & 1 & - & - \\
\hline Devesa da Rogueira & Spain & 15 & -7.08 & 42.25 & 9 & - & - & - & - & - & - & - & - \\
\hline Valle de Salzar & Spain & 16 & -0.92 & 42.83 & 10 & - & - & - & - & - & - & - & - \\
\hline Montejo de la Sierra & Spain & 17 & -3.50 & 41.13 & - & - & - & - & 10 & - & - & - & - \\
\hline Casentinesi & Italy & 18 & 11.8 & 43.78 & 10 & 10 & - & - & - & - & - & - & 9 \\
\hline Bresciano & Italy & 19 & 10.88 & 45.8 & 10 & - & - & - & - & - & - & - & - \\
\hline Calabria & Italy & 20 & 16.58 & 39.00 & 10 & - & - & - & - & - & - & - & - \\
\hline Mt Medvencia & Croatia & 21 & 15.95 & 45.87 & 10 & - & - & - & - & - & - & - & - \\
\hline Savarsin & Romania & 22 & 22.23 & 46.02 & 8 & - & - & - & - & - & - & - & 3 \\
\hline Boki & Slovakia & 23 & 19.12 & 48.57 & 13 & - & - & - & - & - & - & - & - \\
\hline Mt Voras & Greece & 24 & 23.73 & 40.56 & 11 & - & - & - & - & - & - & - & - \\
\hline Voronez reserve & Russia & 25 & 39.5 & 51.83 & 10 & - & - & - & - & - & - & - & - \\
\hline$\Sigma$ & & & & & 240 & 31 & 7 & 5 & 11 & 5 & 2 & 1 & 21 \\
\hline
\end{tabular}

The numbers of individuals analysed from each population and species are given. The species abbreviations represent the following species: $\mathrm{SCI}=$ Salix cinerea, $\mathrm{SAU}=S$. aurita, $\mathrm{SPU}=S$. purpurea, $\mathrm{SAT}=S$. artocinerea, $\mathrm{SAP}=\mathrm{S}$. appendiculata, $\mathrm{SEL}=\mathrm{S}$. elaeagnos, $\mathrm{SFR}=S$. fraglilis, $\mathrm{SAL}=\mathrm{S}$. alba . 


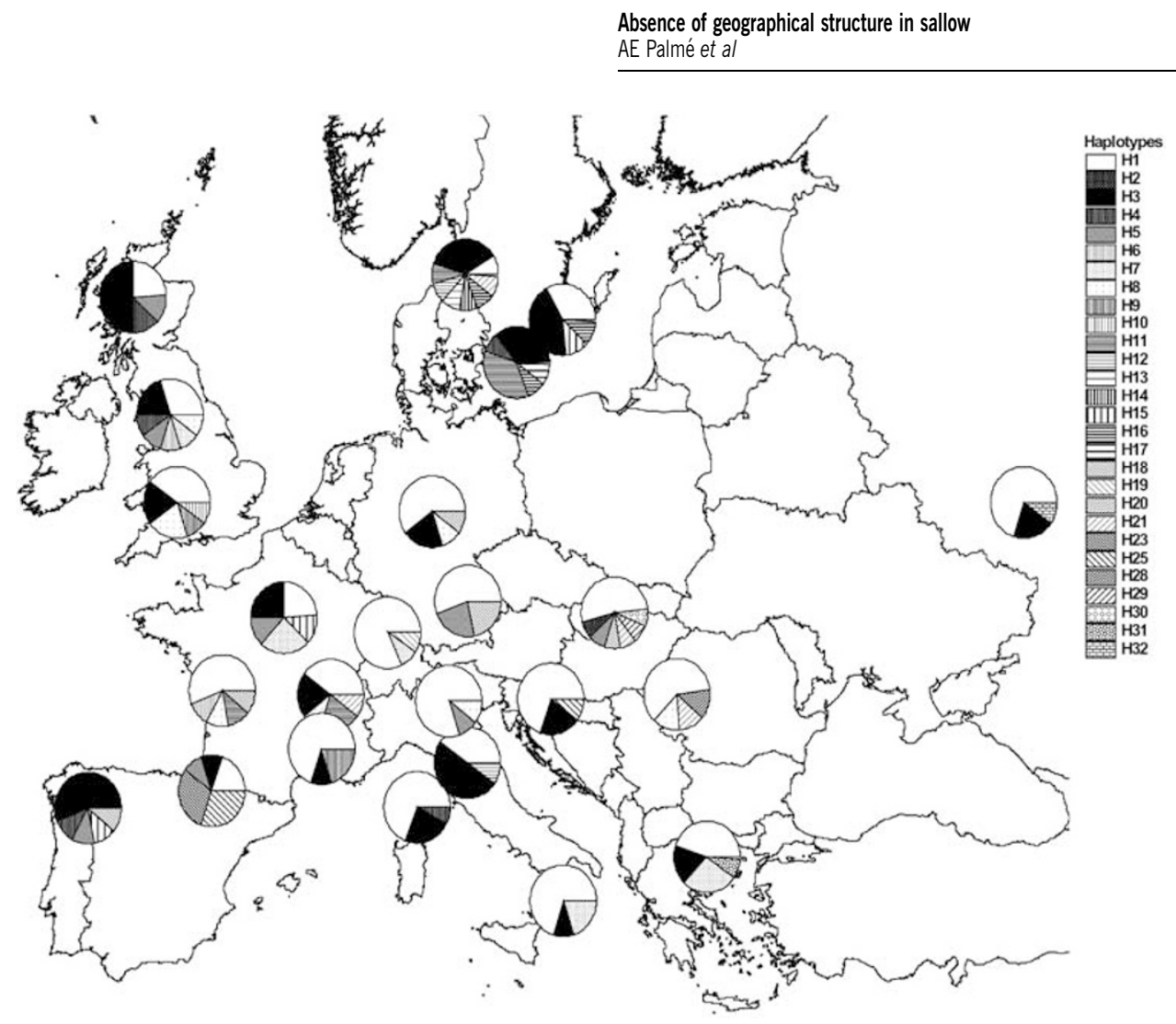

Figure 1 Geographic distribution of chloroplast PCR-RFLP haplotypes in S. caprea.

and PVP (10 g/l), to which 1,4-dithiothreitol was added just before use.

\section{PCR-RFLP analysis}

PCR conditions: Primers from Dumolin-Lapégue et al (1997b) and Démesure et al (1995) (CS, fMA, AS, VL, HK, $\mathrm{K} 1 \mathrm{~K} 2, \mathrm{CD}, \mathrm{DT}, \mathrm{TF})$ were used for the amplification of nine different parts of the chloroplast genome. The PCR was performed in $1 \times$ PCR buffer (Fermentas), $1.8 \mathrm{mM}$ $\mathrm{MgCl}_{2}, 0.2 \mathrm{mg} / \mu \mathrm{l}$ BSA (Fermentas), $0.1 \mathrm{mM} \mathrm{dNTP}$ (Roche), $0.2 \mu \mathrm{M}$ of each primer and $0.016 \mathrm{U} / \mu \mathrm{l} \mathrm{Taq}$ DNA polymerase (Fermentas). A touch-down PCR program was used for the amplification: $4 \mathrm{~min}$ at $94^{\circ} \mathrm{C}$, $14-20$ cycles of $45 \mathrm{~s}$ at $94^{\circ} \mathrm{C}, 45 \mathrm{~s}$ at $60-48^{\circ} \mathrm{C}$ decreasing $0.5^{\circ} \mathrm{C}$ with each cycle to $53-40^{\circ} \mathrm{C}, 3-6 \mathrm{~min}$ at $68-72^{\circ} \mathrm{C}$, then $15-20$ cycles of $45 \mathrm{~s}$ at $94^{\circ} \mathrm{C}, 45 \mathrm{~s}$ at $53-40^{\circ} \mathrm{C}, 3-6 \mathrm{~min}$ at $68-72^{\circ} \mathrm{C}$ and finally $10 \mathrm{~min}$ at $68-72^{\circ} \mathrm{C}$ (the exact temperatures and times depend on the fragment; see Palmé and Vendramin, 2002).

Restriction: Each PCR product was cut with two restriction enzymes: TaqI (Fermentas) and HinfI (Fermentas). The restriction reactions contained $15 \mu \mathrm{l}$ PCR product, $2 \mu \mathrm{l} \mathrm{H}_{2} \mathrm{O}, 1 \times$ buffer (Fermentas) and $3 \mathrm{U}$ enzyme. After mixing these components, the tubes were placed at a temperature optimal to each restriction enzyme, $37^{\circ} \mathrm{C}$ for $\mathrm{HinfI}$ and $65^{\circ} \mathrm{C}$ for TaqI, and left there over night. After the restriction $15 \mu \mathrm{l}$ of stop-solution (formamide with $3 \mathrm{mg} / \mathrm{ml}$ xylencyanol, $3 \mathrm{mg} / \mathrm{ml}$ bromophenol blue and $10 \mathrm{mM}$ EDTA $\mathrm{pH}$ 8) was added to each tube. Just before loading, the restriction mix was heated to $85^{\circ} \mathrm{C}$ for $4 \mathrm{~min}$ and then placed on ice. A volume of $2.4 \mu \mathrm{l}$ of this mix was then loaded onto the gel.
Fragment analysis: The restriction fragments were analysed on a denaturing $6 \%$ acrylamide gel. Samples from the populations of Glen Affric, Halltorp, Kelheim, Chizé, Montejo de la Sierra and Casentinesi were analysed on small gels $(18 \mathrm{~cm} \times 16 \mathrm{~cm} \times 1 \mathrm{~mm})$. Variable fragments were reanalysed on larger but thinner gels $(43 \mathrm{~cm} \times 35 \mathrm{~cm} \times 0.4 \mathrm{~mm})$ together with individuals from the other populations. The buffer used in both cases was $1 \times$ TBE. The small gels were run at $300 \mathrm{~V}$ for $4 \mathrm{~h} 30 \mathrm{~min}$ and were then stained in ethidiumbromide, visualised on a UV-table and photographed. The large gels were run at $2000 \mathrm{~V}$ for 5000 volt hours, silver-stained and then scanned.

Screening: An initial screening of variation was conducted on 49 S. caprea individuals collected in six different localities: Glen Affric, Halltorp, Kelheim, Chizé, Montejo de la Sierra (only two individuals that were not used in further analysis) and Casentinesi. To increase the chances of finding variation, the chosen populations were as geographically distant from each other as was possible at the time. The screening was conducted with nine different universal chloroplast DNA primer pairs (CS, fMA, AS, VL, HK, K1K2, CD, DT, TF from Démesure et al, 1995; Dumolin-Lapégue et al, 1997b) and each PCR product was cut with two restriction enzymes: TaqI and Hinfl. Eight primer enzyme combinations proved to be variable in this sample: TF, K1K2, HK and CD cut with both TaqI and Hinfl. The screening of the total sample of 240 S. caprea individuals, as well as the 83 individuals from the other Salix species, was conducted using only the variable primer enzyme combinations. 
Microsatellites

PCR conditions: Microsatellites ccmp2, ccmp7 and ccmp10 from Weising and Gardner (1999) were amplified according to the following protocol: $5 \mathrm{~min}$ at $95^{\circ} \mathrm{C}, 5 \mathrm{~min}$ at $80^{\circ} \mathrm{C}$ during which the enzyme was added, 30 cycles of $1 \mathrm{~min}$ at $95^{\circ} \mathrm{C}, 1 \mathrm{~min}$ at $50^{\circ} \mathrm{C}, 1 \mathrm{~min}$ at $72^{\circ} \mathrm{C}$, and finally $8 \mathrm{~min}$ at $72^{\circ} \mathrm{C}$. The PCR was performed in $1 \times$ PCR buffer (Pharmacia), $2.5 \mathrm{mM} \mathrm{MgCl}_{2}, 0.2 \mathrm{mM}$ dNTP, $0.2 \mu \mathrm{M}$ of each primer and $0.04 \mathrm{U} / \mu \mathrm{l}$ Taq DNA polymerase (Pharmacia).

Fragment analysis: The success of the amplification was confirmed on agarose gels and the amount of DNA was estimated. The PCR products were then diluted to the appropriate concentration and microsatellites ccmp2, ccmp7 and ccmp10 were mixed for each individual. Sizestandards were added to each mix before loading onto Reprogel Long Read acrylamide gels, which were run on an automated sequencing machine (Alf Express, Pharmacia). The output was then analysed with Fragment Manager 1.2 (Pharmacia).

Screening: In S. caprea 51 individuals from Glen Affric, Halltorp, Kelheim, Chizé, Montejo de la Sierra (only two individuals) and Casentinesi were analysed with three different chloroplast microsatellite primer pairs, ccmp2, ccmp7, ccmp10 (Weising and Gardner, 1999). These primer pairs were chosen from a first screening on eight individuals with six microsatellite primer pairs from Weising and Gardner (1999): ccmp2, ccmp3, ccmp5, ccmp7, ccmp6 and ccmp10. The primers used for further analysis were chosen on the basis of variability and ability to amplify one single PCR product.

\section{Data analysis}

Distribution maps of haplotypes were drawn using ArcView GIS 3.2 (Environmental Systems Research Institute, Inc.,) and a reduced median haplotype network, with equal weighing of the characters, was constructed with Network 3.1.1.1 (Bandelt et al, 1999). The Network package was also used to obtain the mismatch distribution. Under an infinite-site model and neutrality, a constant-size population will lead to an L-shaped distribution whereas a bell-shaped distribution will indicate an expanding population. The skew of the distribution will depend on the time at which the expansion occurred: an early expansion will give a leftskewed distribution and a late expansion a right-skewed one (Rogers and Harpending, 1992; Rogers, 1997).

Calculations of gene diversity within each population (equivalent to expected heterozygosity) were performed using the Arlequin 2.000 package (Schneider et al, 2000). The regression analysis of diversity measures and latitude was performed in MINITAB (Minitab Inc.) where the correlation was tested with a $t$-test. The $G_{\mathrm{ST}}$ and $N_{\mathrm{ST}}$ were calculated with HaPermut 2.1 following Pons and Petit (1996). The introgression ratio, IG, and the expected introgression ratio, $\mathrm{IG}^{\mathrm{e}}$, were calculated according to Belahbib et al (2001). IG reflects the amount of shared haplotypes between two species and is expected to be one when there is no difference between the species and zero when they are totally different. The $\mathrm{IG}^{\mathrm{e}}$ is the expected value if the sharing of haplotypes is not geographically structured, that is, if the presence of a haplotype in one population does not increase the probability of finding this haplotype in the related species in the same area.

\section{Results}

\section{PCR-RFLP}

Variability: The screening of the total sample of 240 S. caprea individuals, as well as the 83 individuals from the other Salix species, was conducted using only the variable primer enzyme combinations: TF, K1K2, HK and CD cut with TaqI and HinfI. The most variable fragment was CD, where seven variable bands were found when cut with HinfI and five when cut with TaqI (Table 2). The other fragments showed lower but still substantial variability. The variation found in all the investigated fragments combined into 35 haplotypes, of which 28 were found in S. caprea (Table 2).

Haplotype network: The haplotype network of the $S$. caprea haplotypes is centred around the two most frequent haplotypes $\mathrm{H} 1$ and $\mathrm{H} 3$ and has a somewhat star-like topology (Figure 2). The mismatch distribution, that is the distribution of pairwise differences, is bellshaped and right-skewed, suggesting a growing population (Rogers and Harpending, 1992; Rogers, 1997) (Figure 3).

Haplotype distribution in Salix caprea: The main feature of the haplotype distribution is the absence of a clear geographic structuring of the haplotypes. The most common haplotype, $\mathrm{H} 1$, is found in 22 of the 24 populations and makes up $46 \%$ of the total sample. Haplotype $\mathrm{H} 3$ is also common and it is present in $20 \%$ of the individuals and in $75 \%$ of the populations (Figure 1). The other 26 haplotypes are rare or very rare as they occur in only $0.4-3.7 \%$ of the individuals, and 12 of these are represented by one single copy. All of the haplotypes found in more than one individual are, with the exception of haplotype $\mathrm{H} 23$, present in more than one population where they are often represented by a single individual. Many of these rare haplotypes are geographically widespread. Haplotype H5, for example, is present in Glen Affric, Lake District (Great Britain), Kelheim (Germany), Fontainbleau (France), Devesa da Rogueira, Valle de Salzar (Spain), Bresciano (Italy) and Boki (Slovakia), even though it is only observed in a total of nine individuals (Figure 1).

Haplotype distribution among species: Many of the haplotypes found in $S$. caprea were also detected in S. cinerea, S. aurita, S. purpurea, S. atrocinerea and/or S. appendiculata (Figure 5). In fact, $54 \%$ of the $S$. caprea haplotypes were shared by one or several of the other species and $75 \%$ of the haplotypes represented by more than one copy in $S$. caprea were found in at least one of the other species. All haplotypes of S. cinerea, S. aurita and $S$. appendiculata were present in $S$. caprea. In S. purpurea, on the other hand, all four individuals from population 14 have haplotype $\mathrm{H} 22$, which is absent in S. caprea. S. atrocinerea has a single haplotype, H27, which is only found in one individual in this species. All haplotypes found in this group of Salix species are very similar (Table 2) except for haplotype H2, which is separated from the rest by at least 19 mutational steps. The IG and the $\mathrm{IG}^{\mathrm{e}}$ were calculated for $S$. caprea and 
Table 2 PCR-RFLP haplotypes, designated by H1-H25, H27-H36, and the band pattern associated with each haplotype

\begin{tabular}{|c|c|c|c|c|c|c|c|c|}
\hline Haplotype & $\begin{array}{c}\text { TF TaqI } \\
\text { band: } 1234\end{array}$ & $\begin{array}{l}\text { TF HinfI } \\
\text { band: } 123\end{array}$ & $\begin{array}{l}\text { K1K2 HinfI } \\
\text { band: } 127\end{array}$ & $\begin{array}{l}\text { K1K2 TaqI } \\
\text { band: } 24\end{array}$ & $\begin{array}{l}\text { HK TaqI } \\
\text { band: } 23\end{array}$ & $\begin{array}{l}\text { HK HinfI } \\
\text { bands: } 15\end{array}$ & $\begin{array}{c}C D \text { HinfI } \\
\text { band: } 1234567\end{array}$ & $\begin{array}{c}C D \text { TaqI } \\
\text { band: } 12345\end{array}$ \\
\hline $\mathrm{H} 1$ & 1111 & 111 & 111 & 11 & 11 & 11 & 1111111 & 11111 \\
\hline $\mathrm{H} 2$ & 2221 & 443 & 122 & 11 & 12 & 11 & 4453122 & 25421 \\
\hline $\mathrm{H} 3$ & 1111 & 111 & 111 & 11 & 11 & 11 & 1111111 & 11211 \\
\hline $\mathrm{H} 4$ & 1111 & 111 & 111 & 11 & 11 & 11 & 2111111 & 12211 \\
\hline H5 & 1111 & 411 & 111 & 11 & 11 & 11 & 1111111 & 11111 \\
\hline $\mathrm{H} 6$ & 1111 & 111 & 211 & 31 & 11 & 11 & 1111111 & 11211 \\
\hline H7 & 1111 & 111 & 111 & 11 & 11 & 11 & 1112111 & 11111 \\
\hline H8 & 1111 & 111 & 111 & 11 & 11 & 11 & 1121111 & 11111 \\
\hline H9 & 1111 & 111 & 111 & 11 & 11 & 11 & 1211111 & 11311 \\
\hline $\mathrm{H} 10$ & 1112 & 111 & 111 & 11 & 11 & 11 & 1111111 & 11211 \\
\hline H11 & 1411 & 151 & 111 & 11 & 11 & 11 & 1111111 & 11211 \\
\hline H12 & 1411 & 151 & 111 & 11 & 11 & 11 & 1121111 & 11211 \\
\hline $\mathrm{H} 13$ & 1111 & 111 & 111 & 11 & 21 & 21 & 1111111 & 11211 \\
\hline H14 & 1111 & 111 & 111 & 11 & 11 & 11 & 1111211 & 11211 \\
\hline H15 & 1111 & 111 & 111 & 11 & 31 & 11 & 1111111 & 11211 \\
\hline H16 & 1111 & 111 & 111 & 12 & 21 & 21 & 1111111 & 11211 \\
\hline H17 & 1111 & 111 & 111 & 12 & 11 & 11 & 1111111 & 11211 \\
\hline H18 & 1111 & 111 & 211 & 21 & 11 & 11 & 1111111 & 11111 \\
\hline H19 & 1511 & 121 & 111 & 11 & 11 & 11 & 1111111 & 11211 \\
\hline $\mathrm{H} 20$ & 1111 & 111 & 111 & 11 & 11 & 11 & 1111111 & 12211 \\
\hline H21 & 1111 & 111 & 111 & 11 & 11 & 12 & 1111111 & 11111 \\
\hline $\mathrm{H} 22$ & 1111 & 511 & 111 & 11 & 11 & 11 & 1111111 & 11111 \\
\hline $\mathrm{H} 23$ & 1111 & 511 & 111 & 11 & 11 & 11 & 1111111 & 11211 \\
\hline $\mathrm{H} 24$ & 2221 & 442 & 122 & 11 & 12 & 11 & 3353122 & 23421 \\
\hline $\mathrm{H} 25$ & 1111 & 111 & 211 & 21 & 11 & 11 & 1112111 & 11211 \\
\hline $\mathrm{H} 27$ & 1111 & 111 & 111 & 11 & 11 & 11 & 1112111 & 11211 \\
\hline $\mathrm{H} 28$ & 1111 & 111 & 111 & 11 & 41 & 31 & 1111111 & 11211 \\
\hline H29 & 4111 & 211 & 111 & 11 & 11 & 11 & 1111111 & 11111 \\
\hline H30 & 1111 & 111 & 111 & 11 & 21 & 21 & 1112111 & 11311 \\
\hline H31 & 1411 & 151 & 111 & 11 & 11 & 11 & 1131111 & 11311 \\
\hline H32 & 1111 & 111 & 111 & 11 & 11 & 11 & 1141111 & 11311 \\
\hline H33 & 2221 & 442 & 122 & 11 & 12 & 11 & 3153122 & 23421 \\
\hline H34 & 2221 & 442 & 122 & 11 & 12 & 11 & 1353122 & 24421 \\
\hline H35 & 2221 & 442 & 122 & 11 & 12 & 11 & 4453122 & 25421 \\
\hline H36 & 3331 & 334 & 211 & 22 & 12 & 11 & 5514133 & 36532 \\
\hline
\end{tabular}

In each column, the variable bands found in a certain fragment (TF, K1K2, HK or CD) cut with restriction enzymes TaqI or Hinfl are given. The different states found for each band are represented by numbers (1-6).

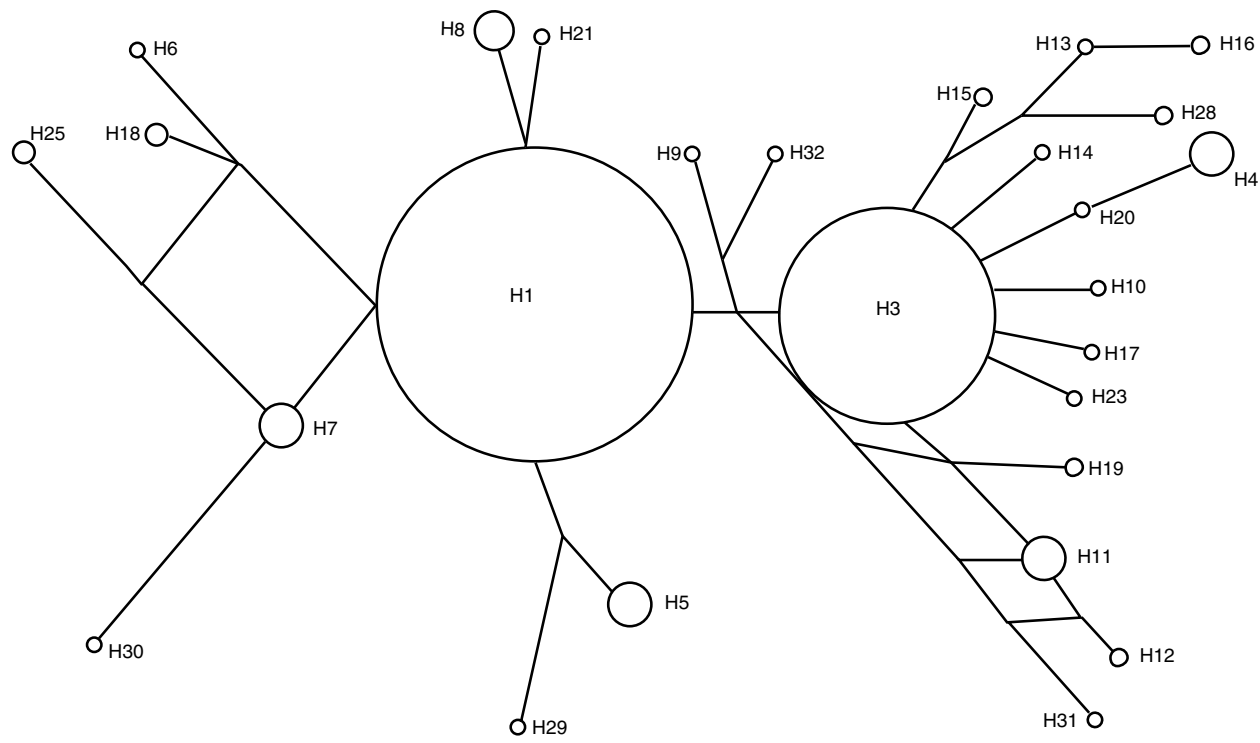

Figure 2 Reduced median haplotype network based on the PCR-RFLP data. Only S. caprea haplotypes are represented and the most common haplotypes, $\mathrm{H} 1$ and $\mathrm{H} 3$, are in the centre of the network. The lengths of the branches are proportional to the number of changes between haplotypes. The sizes of the circles reflect, but are not totally proportional to, the frequency of the haplotypes. 


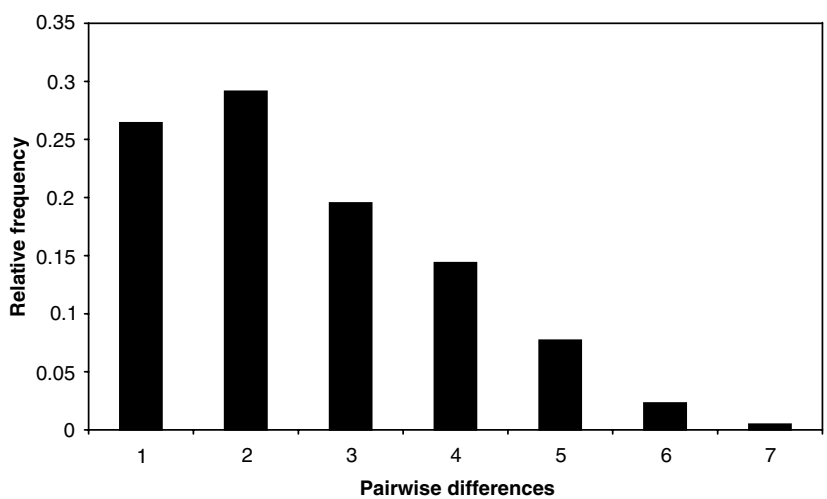

Figure 3 Mismatch distribution (the distribution of pairwise differences) (Rogers and Harpending, 1992) for the PCR-RFLP haplotypes.

S. cinerea, but not for the other species pairs due to low sampling sizes. The resulting IG and $\mathrm{IG}^{\mathrm{e}}$ were 1.05 and 0.50 , respectively.

Haplotypes observed in S. caprea were absent in S. alba, $S$. elaeagnos and $S$. fragilis, but the most common haplotype in S. alba was also found in the few sampled individuals of the other two species (Figure 5). The haplotypes found in this group of Salix species are distinctly different from those found in the $S$. caprea group, except from $S$. caprea haplotype $\mathrm{H} 2$, which is separated by only one mutational step from haplotype H35 in S. alba (Table 2).
Distribution of variation in S. caprea: All populations have a high level of chloroplast DNA variation, and very little of the variation can be attributed to differences between populations $\quad\left(G_{\mathrm{ST}}=0.090, \quad \mathrm{SE}=0.023\right.$, $N_{\mathrm{ST}}=0.095, \mathrm{SE}=0.028$ ). The least variable population has three haplotypes and a haplotype diversity of 0.50 , while the most variable populations have up to eight haplotypes in 11 individuals (Tofta, Sweden) and a diversity of 0.91 (Lake District, Great Britain) (Table 3). There is a tendency for northern populations to be more variable than southern populations (Figure 6): there is a significant correlation between latitude and the number of haplotypes in a population $(P=0.026)$, while the correlation between diversity and latitude is nonsignificant $(P=0.054)$.

\section{Microsatellites}

Microsatellite ccmp7 was monomorphic (135 bp) in the analysed sample and microsatellite ccmp10 had only limited variation, with three size variants (107, 109, $110 \mathrm{bp}$ ) of which two were rare. Microsatellite ccmp2 was much more variable and had five different size variants $(206,208,209,210,211 \mathrm{bp})$. The size variants of microsatellite ccmp2 and ccmp10 combine into eight different haplotypes. The haplotypes $\mathrm{A}$ and $\mathrm{C}$ are common, occurring in 31 and $43 \%$ of the individuals. They are also widely distributed geographically (Figure 4): $\mathrm{A}$ is present in all populations and $C$ in all populations except one (Montejo de la Sierra), but that might simply be due to the low sample size in this population. Haplotypes B and $\mathrm{D}$ are less common but they are also geographically

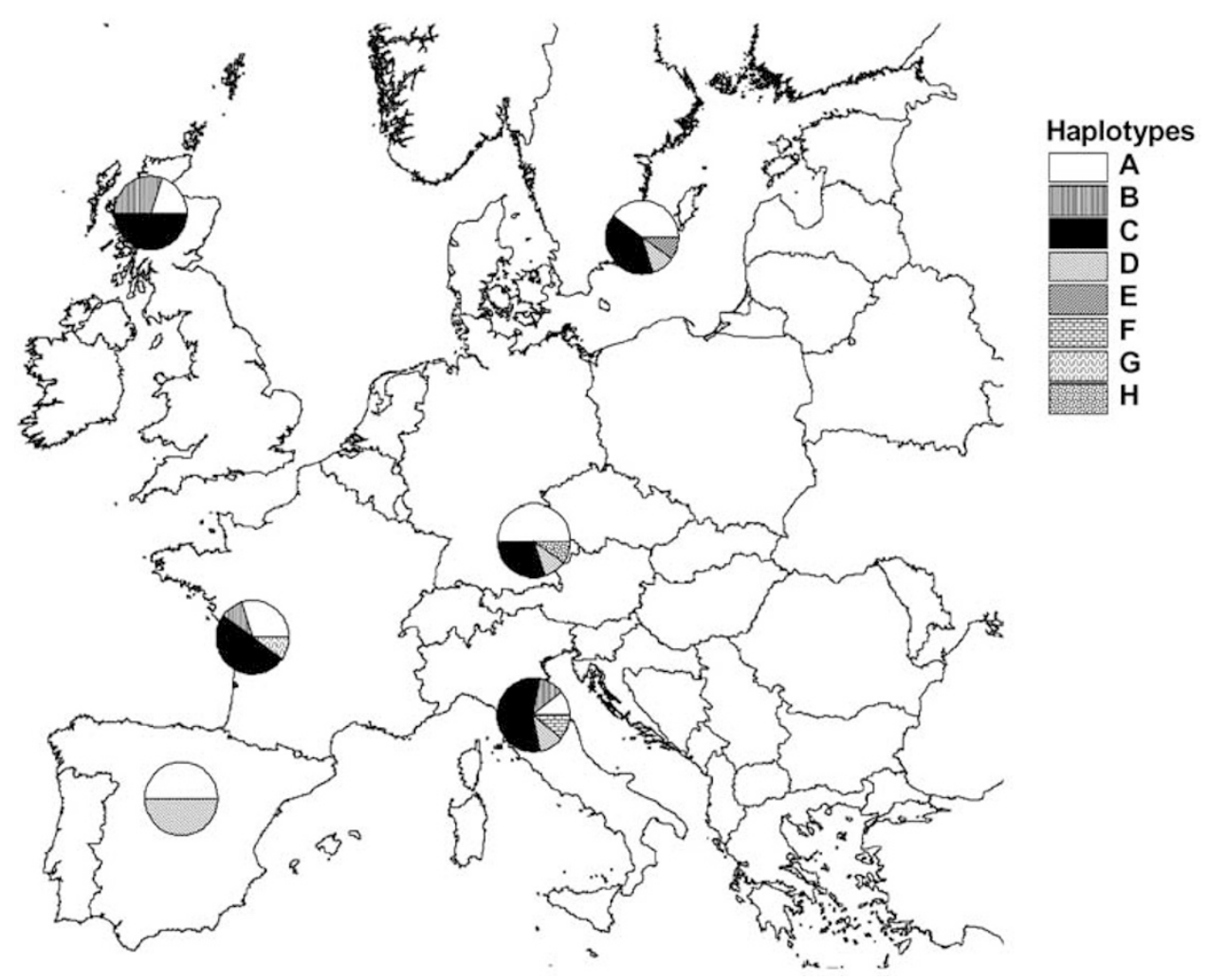

Figure 4 Geographic distribution of chloroplast microsatellite haplotypes in S. caprea. 


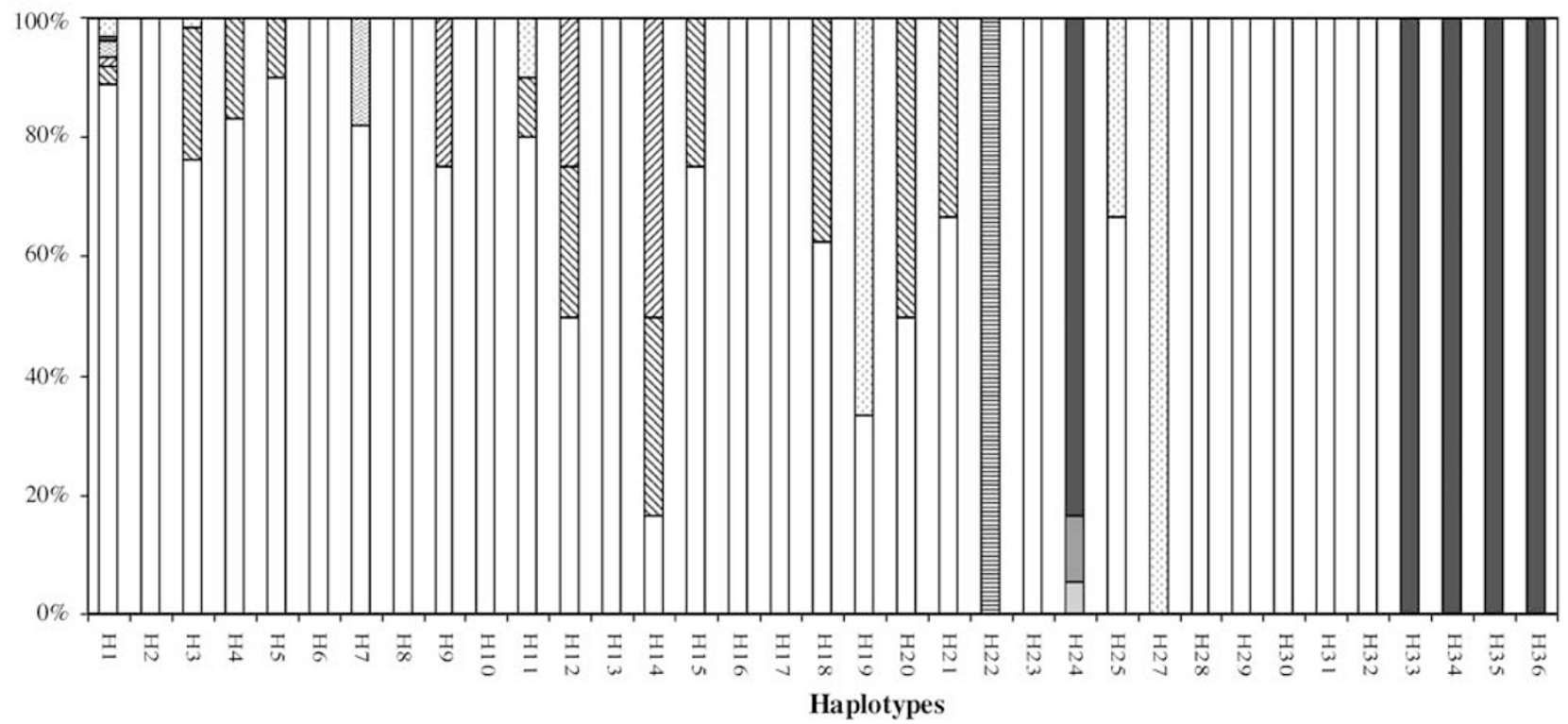

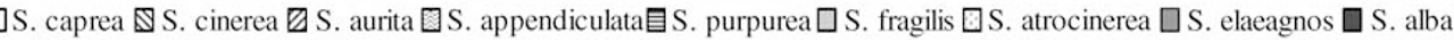

Figure 5 Sharing of haplotypes among the nine investigated Salix species. Each column represents one haplotype and its distribution among the species.

Table 3 Diversity and number of haplotypes in the investigated S. caprea populations

\begin{tabular}{lccc}
\hline Population & $\begin{array}{c}\text { Number of } \\
\text { individuals }\end{array}$ & $\begin{array}{c}\text { Number of } \\
\text { haplotypes }\end{array}$ & Diversity \\
\hline Glen Affric & 8 & 4 & 0.75 \\
Lake District & 10 & 7 & 0.91 \\
Dean & 10 & 5 & 0.82 \\
Tofta & 11 & 8 & 0.89 \\
Stenshuvud & 11 & 5 & 0.78 \\
Halltorps Hage & 9 & 4 & 0.75 \\
Seebachtal & 11 & 3 & 0.35 \\
Bovenden & 10 & 4 & 0.64 \\
Kelheim & 9 & 3 & 0.67 \\
Fontainbleau & 8 & 5 & 0.89 \\
Chizé & 9 & 5 & 0.72 \\
Seillon & 10 & 5 & 0.82 \\
Valbonne & 10 & 3 & 0.51 \\
Valdu Niellu, Aitone & 13 & 3 & 0.50 \\
Devesa da Rogueira & 9 & 5 & 0.72 \\
Valle de Salzar & 11 & 5 & 0.84 \\
Casentinesi & 10 & 3 & 0.64 \\
Bresciano & 10 & 3 & 0.38 \\
Calabria & 10 & 3 & 0.51 \\
Mt Medvencia & 10 & 3 & 0.51 \\
Savarsin & 8 & 4 & 0.64 \\
Boki & 13 & 6 & 0.68 \\
Mt Voras & 11 & 4 & 0.75 \\
Voronez reserve & 10 & 3 & 0.51 \\
Gora & &
\end{tabular}

widespread. The other haplotypes occurred only in single individuals.

Population differentiation was basically nil $\left(G_{\mathrm{ST}}=\right.$ $\left.-0.017, \mathrm{SE}=0.0187 ; N_{\mathrm{ST}}=0.005, \mathrm{SE}=0.0025\right)$. The $G_{\mathrm{ST}}$ and $N_{\mathrm{ST}}$ values are based on only five populations as Montejo de la Sierra was excluded because of its limited sample size.

\section{Discussion}

In a recent review, entitled The genetic legacy of the Quaternary Ages, Hewitt (2000) describes the types of patterns unravelled by previous phylogeographic studies (his Figure 2) and shows three patterns of recolonisation from refugia in southern Europe. This picture certainly captures most of the patterns observed so far in both plants and animals. However, it fails to represent $S$. caprea, and probably would not do justice to other cold-tolerant pioneer species that simply may not have been confined to southern Europe during the LGM. This is, for example, the case for Calluna vulgaris, a coldtolerant species with a similar distribution as $S$. caprea (Rendell and Ennos, 2002), and for Arctic species (Tollefsrud et al, 1998; Abbott et al, 2000). The lack of phylogeographic structure in $S$. caprea might be the consequence of one or more of several factors: (i) lack of well-defined southern refugia, (ii) rapid speed of recolonisation and high dispersal ability, (iii) high mutation rates and (iv) extensive hybridisation with other willow species.

\section{Glacial refugia and dispersal}

The occurrence of small, isolated populations in buffered microclimates close to the ice sheet during the LGM has been controversial but is now slowly gaining acceptance (Willis et al, 2000; Stewart and Lister, 2001; but see Carcaillet and Vernet, 2001). Evidence from macroscopic charcoal records confirms the presence of Salix sp and seven other woody species in Hungary during the last full-glaciation (Willis et al, 2000). This does not necessarily mean that $S$. caprea was present, since it is not possible to distinguish fossils of different Salix species and there is little hope that it will be possible in the near future, unless seed or leaf fossils are available (K Bennett, 

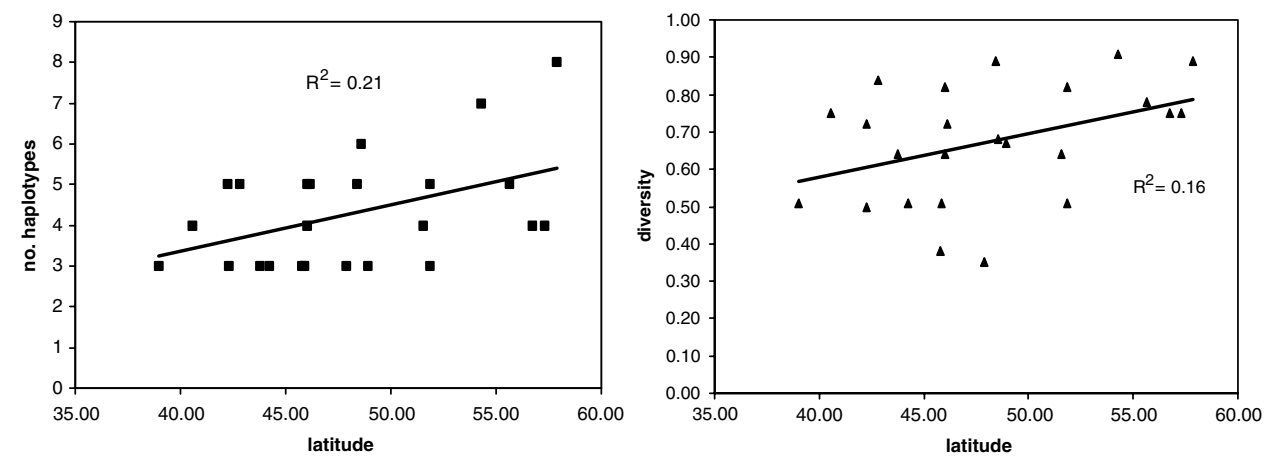

Figure 6 Correlation between latitude and the number of haplotypes in a population as well as between latitude and diversity. The former correlation is significant $(P=0.026)$ but the latter is not $(P=0.054)$. The linear regression line and its coefficient of determination $\left(R^{2}\right)$ are represented in both graphs.

personal communication). Unfortunately, the pollen fossil record is also not very informative since again $S$. caprea cannot be distinguished from other Salix species. Nonetheless, the presence of Salix sp, as well as $P$. sylvestris, P. cembra, Betula sp, Picea sp, Juniperus sp, Larix $\mathrm{sp}$ and Carpinus betulus in Hungary during LGM, indicates that the climate, at least locally, was suitable for $S$. caprea. Important refugia at intermediate latitudes are thus possible.

Since S. caprea cannot be separated from other Salix species in the pollen fossil record, the speed of recolonisation is difficult to infer. However, even if we assume that the Salix genus spent the LGM in Central Europe, its presence $16000 \mathrm{BP}$ in southern Scandinavia (Brewer, 2002) implies rapid migration. Trees can indeed spread very fast; for instance, the white spruce in the Western Interior (Canada) spread across $2000 \mathrm{~km}$ during roughly 1000 years. In this case, strong surface winds and flat open terrain could have affected the rapid seed dispersal over large distances (Ritchie and McDonald, 1986). The seeds of S. caprea are dispersed by wind (Rameau et al, 1989) and have therefore a great dispersal potential, especially in the open landscape of recently deglaciated Europe, where strong winds may also have prevailed during the recolonisation. The high dispersal ability of sallow might also have continued to affect its genetic structure since seed dispersal between populations should prevent population differentiation and cause a wider distribution of the haplotypes. The pattern found in S. caprea, where not only common haplotypes but also rare ones are widely distributed geographically, could thus be due, at least in part, to the high dispersal ability of the species.

In most species studied so far there is a tendency for southern populations to show more variation than northern populations (Fagus sylvatica: Démesure et al, 1996; Alnus glutinosa: King and Ferris, 1998; Quercus: Petit et al, 2002) but in $S$. caprea the opposite trend is observed and most variation is found in the north (Figure 6, Table 3). A similar trend could be observed in C. vulgaris, where haplotype diversity within populations was higher in the northern part of the range than in the southern $\left(h_{\mathrm{s}}(\right.$ north $)=0.576, h_{\mathrm{s}}($ south $\left.)=0.322\right) \quad($ Rendell and Ennos, 2002). In Calluna as well as in Salix, refugia outside the traditional southern refugia have been suggested and this would certainly affect the distribution of variation and increase the amount of variation at higher latitudes.

\section{Genetic variation and mutation rates}

Compared to most other tree species, S. caprea exhibits very high levels of chloroplast DNA variation. When similar sampling and molecular methods were used in many other tree species such as Acer campestre, Acer pseudoplatanus, A. glutinosa, Betula pendula, C. betulus, F. sylvatica, Fraxinus excelsior, Quercus robur, Tilia cordata and Ulmus minor, between 5 and 17 haplotypes were found at the European scale and the differentiation between populations was generally high $\left(0.40 \leq G_{\mathrm{ST}} \leq 0.97\right)$ in most of these species (Petit et al, 2001). In contrast, in $S$. caprea, 28 haplotypes were detected and very little of the variation is due to differentiation between populations $\left(G_{\mathrm{ST}}=0.09\right)$. A similar pattern can be found in another Salicaceae, Populus tremula, where 21 haplotypes were found with PCR-RFLP and the $G_{S T}$ value is low (0.12) (Bittkau and Müller-Stark, in preparation). Interestingly enough it seems to be the same parts of the genome that are responsible for most of the variation in both species since the same PCR-RFLP marker (CD) and microsatellite marker (ccmp2) show the highest levels of variation in both species. High levels of chloroplast DNA variation have also been found in other Salix species such as $S$. interior, S. melanopsis and S. exigua (Brunsfeld et al, 1992), and the comparison of nucleotide variation in the $\mathrm{K} 1 \mathrm{~K} 2$ region among 14 species (Grivet, 2002) showed a high level of variation in S. caprea. High rates of substitution can obscure geographical patterns since homoplasy can create haplotypes that are identical by state but not by descent. This could potentially also affect the geographical structure in S. caprea.

\section{Hybridisation}

The presence of shared haplotypes between $S$. caprea and S. cinerea, S. aurita, S. purpurea, S. atrocinerea and/or S. appendiculata together with their absence within S. alba, $S$. elaeagnos or $S$. fragilis suggests that hybridisation takes place between $S$. caprea and the former, but not with the latter. Alternative explanations could be lineage sorting or convergence, identical haplotypes in the different species having independent origin. Given the extent and pattern of haplotype sharing among the species, these explanations seem less likely than hybridisation. Nonmolecular data support hybridisation between many pairs from the first group and also between S. alba and S. fragilis (Tutin et al, 1964; Meikle, 1992; Rechinger, 1992). 
Salix phylogenies based on ITS sequences (Leskinen and Alström-Rapaport, 1999) showed that, although the differentiation among Salix species was generally low, $S$. alba and $S$. fragilis belonged to a separate clade. Unfortunately, S. caprea was not included in this phylogeny but $S$. purpurea, with which $S$. caprea seems to hybridise, was included and it does not belong to the $S$. alba clade. The traditional Salix taxonomy also supports this division. Skvortsov (1968) puts S. alba and S. fragilis into subgenus Salix, subsection Salix and S. caprea, S. cinerea, S. aurita, S. atrocinerea and S. appendiculata into subgenus Vetrix, subsection Vetrix. The separation of the subgenus Vetrix from most of the species from subgenus Salix is also supported by phylogenies based on the chloroplastic rbcL gene (Azuma et al, 2000), and by our data. The PCR-RFLP data show that the haplotypes found in S. alba, $S$. elaeagnos and $S$. fragilis are very different from those found in the other species (Table 2). What the cause of this hybridisation barrier might be is difficult to say but the two subgenera are not separated by differences in polyploidy levels (Blackburn and Harrison, 1924; Tutin et al, 1964; Thibault, 1998) and the individuals studied have largely overlapping distributions (Jalas et al, 1996).

When species share haplotypes to the extent that $S$. caprea, S. cinerea, S. aurita, S. atrocinerea and S. appendiculata do, it is difficult to identify in which species each haplotype has its origin. It is very improbable, though, that all the haplotypes found in S. caprea were created there and it is safe to assume that many of these haplotypes have their origin in other species. This will of course significantly affect the genetic structure of a species and would have a somewhat similar effect to an increased population size or immigration. Repeated transfer of genes between species is expected to result in an increased number of haplotypes and therefore a high level of genetic variation, such as in $S$. caprea. Notably, the occurrence of some rare haplotypes over a large geographical range could be explained by occasional introgression in S. caprea of haplotypes that are in high frequency in related species.

The chloroplast genetic structure of many other species has also been influenced by hybridisation to various degrees (Wagner et al, 1987; Bobola et al, 1996; DumolinLapégue et al, 1997a; Terry et al, 2000). In some cases only a limited number of individuals in a hybrid zone are affected, while in others hybridisation concerns the whole species. The IG, which can be used to compare different pairs of species, is an attempt to quantify hybridisation, or rather the extent of gene sharing (Belahbib et al, 2001). The IG ratio for S. caprea and S. cinerea is 1.05 , which means that these two species are not differentiated with regard to chloroplast DNA haplotypes, suggesting high levels of introgression. This ratio is in fact higher than in any other species investigated so far. In different pairs of oak species, the ratio ranges from 0.63 to 0.97 (Belahbib et al, 2001) and in species pairs in Alnus, Betula, Crataegus, Fraxinus, Rubus and Tilia it ranges from 0.17 to 0.89 .

In the case of the oak species complex, which exhibits high IGs, a large number of closely related species share the locally common chloroplast haplotype whenever they are sympatric (Petit et al, 1993, Dumolin-Lapégue et al, 1997a). This kind of pattern is much more difficult to detect in a species that shows little or no geographic structure. To investigate whether there actually is an increased chance of locally finding an allele in $S$. cinerea if it is present in S. caprea (or vice versa), we compared the IG with the IG $\mathrm{If}^{\mathrm{e}}$ there were no geographic concordance between the species. The IG (1.05) is in this case much higher than the expected value (0.50) indicating local hybridisation and introgression. Hybrids between these two species have also been identified with traditional methods (Meikle, 1984; Rechinger, 1992) and there may be plenty of opportunity for hybridisation due to their largely overlapping distributions (Jalas et al, 1996).

\section{Acknowledgements}

We thank Annette Johansson, Adrien Le Pichon and Peter Henriksson for their kind help with field work and also all the members of the CYTOFOR project as well as Danko Slade (Croatia), Dusan Gömöry (Slovakia) and Flaviu Pospescu (Rumania) for invaluable assistance with sampling. The study has been carried out with financial support from the Commission of the European Communities, Agriculture and Fisheries (FAIR) specific RTD programme, CT97-3795, CYTOFOR. VS was supported by a grant from the Royal Swedish Academy of Sciences.

\section{References}

Abbott RJ, Smith LC, Milne RI, Crawford RMM, Wolff K, Balfour J (2000). Molecular analysis of plant migration and refugia in the Arctic. Science 289: 1343-1346.

Azuma T, Kajita T, Yokoyama J, Ohashi H (2000). Phylogenetic relationships of Salix (Salicaceae) based on $r b c L$ sequence data. Am J Bot 87: 67-75.

Bandelt H-J, Forster P, Röhl A (1999). Median-joining networks for inferring intraspecific phylogenies. Mol Biol Evol 16: $37-48$.

Belahbib N, Pemonge M-H, Ouassou A, Sbay H, Kremer A, Petit RJ (2001). Frequent cytoplasmic exchanges between oak species that are not closely related: Quercus suber and $Q$. ilex in Morocco. Mol Ecol 10: 2003-2012.

Bennett KD(1997). Evolution and Ecology. The Pace of Life. Cambridge University Press: Cambridge.

Bittkau C, Müller-Starck G. Chloroplast DNA variation of Populas tremula L. in Europe: consequences of multiple glacial refugia and effective seed dispersal. In preparation.

Blackburn KB, Harrison JWH (1924). A preliminary account of the chromosomes and chromosome behaviour in the Salicaceae. Ann Bot 38: 361-378.

Bobola M, Eckert R, Klein A, Stapelfeldt K, Hillenberg K, Gendreau S (1996). Hybridisation between Picea rubens and Picea marina: differences observed between mountain and coastal island populations. Can J For Res 26: 444-452.

Bousquet J, Strauss SH, Doerksen AH, Price RA (1992). Extensive variation in the evolutionary rate of $r b c \mathrm{~L}$ gene sequences among seed plants. Proc Natl Acad Sci USA 89: 7844-7848.

Brewer S (2002). Recolonisation postglaciaire de quelques taxons tempérés en Europe: Une approche spatiale et temporelle. PhD Thesis, Institut Méditerraneen d'Ecologie et de Paléoécologie, Faculté des Sciences de St-Jérome, Université de Marseille.

Brunsfeld SJ, Soltis DE, Soltis PS (1992). Evolutionary patterns and processes in Salix sect. Longifoliae: evidence from chloroplast DNA. Syst Bot 17: 239-256.

Carcaillet C, Vernet JL (2001). Comments on 'The full-glacial forests of central and south-eastern Europe' by Willis et al. Quat Res 55: 385-387. 
Démesure B, Sodzi N, Petit RJ (1995). A set of universal primers for amplification of non-coding regions of mitochondrial and chloroplast DNA in plants. Mol Ecol 4: 129-131.

Démesure B, Comps B, Petit RJ (1996). Chloroplast DNA phylogeography of the common beech (Fagus sylvatica L.) in Europe. Evolution 50: 2515-2520.

Dumolin S, Demesure B, Petit RJ (1995). Inheritance of chloroplast and mitochondrial genomes in pedunculate oak investigated with an efficient PCR method. Theor Appl Genet 91: 1253-1256.

Dumolin-Lapégue S, Demesure B, Fineschi S, Le Corre V, Petit RJ (1997a). Phylogeographic structure of white oaks throughout the European continent. Genetics 146: 1475-1487.

Dumolin-Lapégue S, Pemonge M, Petit R (1997b). An enlarged set of consensus primers for the study of organelle DNA in plants. Mol Ecol 6: 393-397.

Doyle JJ, Doyle JL (1990). Isolation of plant DNA from plant tissue. Focus 12: 13-15.

Grivet D (2002). Phylogéographie et évolution moléculaire comparée d'arbres forestiers à l'aide des marqueurs chloroplastiques. PhD Thesis, Universie Henry Poincaré, Nancy-I.

Hewitt G (2000). The genetic legacy of the Quaternary ice ages. Nature 405: 907-913.

Huntley B, Birks HJB (1983). An Atlas of Past and Present Pollen Maps for Europe: 0-13 000 Years Ago. Cambridge University Press; Cambridge.

Jalas J, Suominen J, Lampinen R (1996). Atlas Florae Europaeae. Distribution of Vascular Plants in Europe, Vol 11. The Committee for Mapping the Flora of Europe \& Societas Biologica Fennica Vanam: Helsinki.

King RA, Ferris C (1998). Chloroplast DNA phylogeography of Alnus glutinosa (L.) Gaertn. Mol Ecol 7: 1151-1161.

Leskinen E, Alström-Rapaport C (1999). Molecular phylogeny of Salicaceae and closely related Flacourtiaceae: evidence from 5.8 S, ITS 1 and ITS 2 of the rDNA. Plant Syst Evol 215: 209-227.

Meikle RD (1984). Willows and poplars of Great Britain and Ireland. Botanical Society of the British Isles, London.

Meikle RD (1992). British willows; some hybrids and some problems. Proc R Soc Edinb 98B: 13-20.

Palmé AE, Vendramin GG (2002). Chloroplast DNA variation, postglacial recolonisation and hybridisation in hazel, Corylus avellana. Mol Ecol 11: 1769-1779.

Petit RJ, Kremer A, Wagner DB (1993). Geographic structure of chloroplast DNA polymorphisms in European oaks. Theor Appl Genet 87: 122-128.

Petit RJ, Csaikl UM, Bordács S, Burg K, Cuart E, Cuttrell J et al (2002). Chloroplast DNA variation in European white oaks. Phylogeography and patterns of diversity based on data from over 2600 populations. For Ecol Manage 156: 5-26.

Petit R, Legay M, Demesure B (2001). Phylogeography of European forest trees and shrubs and application for their conservation and management. Institut National de Recherche Agronomique, Office National des Forêts, Fountainebleau, Paris.

Pons O, Petit RJ (1996). Measuring and testing genetic differentiation with ordered versus unordered alleles. Genetics 144: 1237-1245.
Rajora OP, Dancik BP (1992). Chloroplast DNA inheritance in Populus. Theor Appl Genet 84: 280-285.

Rameau JC, Mansion G, Dumé G (1989). Flore forestière française. Guide écologique illustré. 1. Plaines et collines. Institut pour le Développement Forestier: Paris.

Rechinger KH (1992). Salix taxonomy in Europe-problems, interpretations, observation. Proc $R$ Soc Edinb 98B: 1-12.

Rendell S, Ennos RA (2002). Chloroplast DNA diversity in Calluna vulgaris (heather) populations in Europe. Mol Ecol 11: 69-78.

Ritchie JC, McDonald GM (1986). The patterns of post-glacial spread of white spruce. J Biogeogr 13: 527-540.

Rogers AR (1997). Population structure and modern human origins. In: Donnelly P, Tavaré S (eds) Progress in Population Genetics and Human Evolution, Springer: New York. pp 55-79.

Rogers AR, Harpending H (1992). Population growth makes waves in the distribution of pairwise genetic differences. Mol Biol Evol 9: 552-569.

Schneider S, Roessli D, Excoffier L (2000). Arlequin v.2.000. A Software for Population Genetics Data Analysis. Genetics and Biometry Laboratory, Department of Ecology and Anthropology, University of Geneva, Geneva.

Skvortsov AK (1968). Willows of the USSR. A taxonomic and geographic survey. Proceedings of the Study of the Fauna and Flora of the USSR. Moscow Society of Naturalists, New series Botany section 15 .

Stewart JR, Lister AM (2001). Cryptic northern refugia and the origins of the modern biota. Trends Ecol Evol 16: 608-613.

Taberlet P, Fumagalli L, Wust-Saucy AG, Cosson JF (1998). Comparative phylogeography and postglacial colonisation routes in Europe. Mol Ecol 7: 453-464.

Terry RG, Nowak RS, Tausch RJ (2000). Genetic variation in chloroplast and nuclear ribosomal DNA in Utah juniper (Juniperus osteosperma, Cupressaceae): evidence for interspecific gene flow. Am J Bot 87: 250-258.

Thibault J (1998). Nuclear DNA amount in pure species and hybrid willows (Salix): a flow cytometric investigation. Can J Bot 76: 157-165.

Tollefsrud MM, Bachmann K, Jakobsen KS, Brochman C (1998). Glacial survival does not matter-II: RAPD phylogeography of Nordic Saxifraga cespitosa. Mol Ecol 7: 1217-1232.

Tutin TG, Heywood VH, Burges NA, Walters SM, Webb DA (1964). Flora Europaea, Vol 1. Cambridge University Press: Cambridge.

Wagner DB, Furnier GR, Saghai-Maroof MA, Williams SM, Dancik BP, Allard RW (1987). Chloroplast DNA polymorphisms in lodgepole and jack pines and their hybrids. Proc Natl Acad Sci USA 84: 2097.

Vendramin GG, Anzidei M, Madaghiele A, Sperisen C, Bucci G (2000). Chloroplast microsatellite analysis reveals the presence of population subdivision in Norway spruce (Picea abies K.). Genome 43: 68-78.

Weising K, Gardner RC (1999). A set of conserved PCR primers for the analysis of simple sequence repeat polymorphisms in chloroplast genomes of dicotyledonous angiosperms. Genome 42: 9-19.

Willis KJ, Rudner E, Sümegi P (2000). The full-glacial forests of central and southern Europe. Quat Res 53: 203-213. 